\title{
Analiza uporabe hrvatskih egzonima s obzirom na obilježja geografskoga objekta
}

\author{
Ivana Crljenko \\ Leksikografski zavod Miroslav Krleža, Zagreb \\ ivana.crljenko@1zmk.hr
}

SAŽETAK: Uporaba egzonima jedan je od najranijih izazova za stručnjake koji se na međunarodnoj razini bave geografskim imenima. Prevladavajuće je motrište da egzonimi ometaju međunarodnu komunikaciju pa njihovu uporabu treba smanjiti. Drugo je mišljenje da su egzonimi sastavni dio rječnika jezične zajednice koja ih stvara i rabi, važan su dio njezina kulturnog nasljeđa i identiteta te ih ne treba zanemarivati. U novije se vrijeme učvršćuje ideja o srednjem rješenju prema kojem egzonime treba rabiti različito, ovisno o dobnim skupinama korisnika, namjeni publikacije i vrsti komunikacije (međunarodnoj ili nacionalnoj). Slijedeći to motrište, članovi Radne skupine za egzonime pri UNGEGN-u donijeli su zaključke vezane uz globalno zajedničke karakteristike egzonima i kriterije njihove uporabe. Tri kriterija odnose se na obilježja geografskoga objekta za koji se rabi egzonim (tip, veličina, važnost, poznatost i lokacija objekta). U radu se kvantitativnom analizom brojnosti i zastupljenosti hrvatskih egzonima u nekoliko kategorija pokazuje da je uporaba hrvatskih egzonima sukladna tim kriterijima, što znači da se egzonimi rabe: a) kad geografski objekt ima bliske i tradicionalne veze s hrvatskom jezičnom zajednicom, a najčešće je riječ o geografski bližim objektima; b) kad je objekt povijesno ili danas važan, globalno i/ili za hrvatske govornike; c) kad se objekt prostire na više govornih područja.

Ključne riječi: hrvatski egzonimi; prilagođenice; uporaba egzonima; UNGEGN

\section{Uvod}

Kao prilagođena, udomaćena ili pohrvaćena imena ${ }^{1}$ geografskih objekata, smještenih izvan hrvatskoga jezičnog područja, koja se u većoj ili manjoj mjeri razlikuju od izvornih imena, hrvatski su egzonimi (prilagođenice) sastavni dio rječnika hrvatskoga jezika te se njima svakodnevno služimo u općoj uporabi - u govoru, pisanju popularnoga, stručnoga ili znanstvenoga teksta, izradi karte, školskoga atlasa ili udžbenika, prevođenju, u medijima i dr. Unatoč dugotrajnoj prisutnosti u hrvatskom jeziku, uz egzonime se i danas vežu sljedeće nedoumice: a) koje je geografsko ime egzonim, a koje endonim (izvorno ime), što je rezultat donedavno neusuglašene definicije dva-

1 Termin »ime« u radu označava geografsko ime (toponim), a »objekt« geografski objekt. 
ju pojmova; b) koji prilagođeni lik upotrijebiti ako ih ima više, odnosno ako je zabilježena višeimenost, što je rezultat činjenice da ih dosad nismo standardizirali; c) koji je egzonim zastario pa ga više ne treba rabiti - osim u povijesnom kontekstu - a koji je još uvijek u uporabi, što je rezultat činjenice da ih doskora nismo niti popisali, a kamoli sustavno analizirali; d) kad upotrijebiti egzonim, a kad endonim, što je rezultat nejasnih kriterija uporabe. $U$ ovom se radu apostrofira upravo problem posljednje dileme - njihove nejasne, nedosljedne i neujednačene primjene u općoj uporabi. ${ }^{2}$

Za mnoge prilagođenice uporaba nam nije sporna jer je egzonim toliko ustaljen $u$ hrvatskom jeziku da isprva ne znamo njegovo izvorno ime. Primjerice, nećemo dvojiti trebamo li upotrijebiti Beč, Veneciju, Island, Stjenjak, Alpe, Dunav ili Dansku kad se obraćamo govornicima hrvatskoga jezika. Međutim, problem nastaje kad nam egzonim nije toliko poznat ili je u govoru i pisanju podjednako često zastupljeno i prilagođeno i izvorno ime. Tada se najčešće pitamo u kojim kontekstima i situacijama za neki objekt trebamo upotrijebiti njegovo prilagođeno ime, ako ga taj objekt ima, a u kojima izvorno. Na primjer, ako je riječ o manjem, udaljenom objektu u nama ne odveć bliskoj jezičnoj zajednici koji ima hrvatsku prilagođenicu, ali se ona rjeđe rabi, a ime trebamo upisati u stručni tekst ili srednjoškolski atlas, vrlo vjerojatno ćemo dvojiti oko uporabe egzonima. Razvidno je, dakle, da uporaba egzonima ovisi o više čimbenika: svrsi i namjeni njegove uporabe, veličini, važnosti i udaljenosti geografskog objekta, poznavanju jezika izvornoga imena te povezanosti sa zajednicom unutar koje se objekt nalazi.

S izazovom primjerenoga tretmana i uporabe egzonima susreću se i drugi jezici, tj. druge zajednice jezika primatelja stranih geografskih imena. Zato je upravo određivanje zajedničkih obilježja i možebitno globalno primjenjivih kriterija uporabe egzonima jedan od zadataka Radne skupine za egzonime, koja od 2002. djeluje unutar međunarodnoga tijela zaduženoga za pitanja o geografskim imenima - Skupine stručnjaka za geografska imena pri Ujedinjenim narodima (UNGEGN) (URL1; URL2).

2 Uporaba toponima u međunarodnoj komunikaciji (npr. u zračnom i poštanskom prometu) uglavnom je jasna. Valja rabiti izvorna imena, i to standardizirana i/ili službena ako postoje (npr. Côte d'Ivoire, El Salvador, Kyïv). Ako je riječ o sporazumijevanju na jeziku koji govornicima nije materinski, treba rabiti egzonime jezika na kojem se sporazumijeva (npr. Parigi za Pariz ako se sporazumijeva na talijanskom jeziku). U vrlo specifičnoj diplomatskoj komunikaciji trebalo bi rabiti službene egzonime država. Neka su od tih imena prilagođena sukladno normama i tradiciji hrvatskog jezika (npr. Alžir, Belgija, Grčka). Druga su prema zahtjevima određenih država prilagođena u manjoj mjeri (npr. Bjelarus, Češka Republika, Kabo Verde) ili su ostavljena u izvornom liku (npr. Côte d'Ivoire, El Salvador) te su prihvatljiva samo u diplomatske svrhe i ako na tome ustraje vrh te države. U službenoj komunikaciji (npr. u dokumentima ministarstava i drugih tijela državne uprave) ipak ne treba inzistirati na diplomatskoj uporabi egzonima; bolje je rabiti egzonime koji su se ustalili u općoj uporabi (npr. Češka, a ne Češka Republika). 


\section{Cilj istraživanja, metoda $i$ metodološke napomene}

Cilj je istraživanja predstavljenoga u radu s pomoću kvantitativne analize odabranih atributa ispitati uporabu hrvatskih egzonima s obzirom na obilježja geografskoga objekta - tip, veličinu, važnost, poznatost i lokaciju. Analizom se želi pokazati da je uporaba hrvatskih egzonima sukladna globalnim kriterijima uporabe egzonima koji se odnose na geografski objekt (kriteriji 3., 4. i 5. u poglavlju 3). Za potrebe istraživanja, iz baze ${ }^{3}$ su uz svaki egzonim ekstrahirana četiri atributa (kategorije) koji opisuju glavna obilježja geografskoga objekta: a) tip objekta; b) podtip objekta; c) lokacija objekta (kontinent ili ocean); d) lokacija objekta (država ili more), i jedan atribut koji se odnosi na jezično obilježje egzonima: e) jezik izvornoga imena. ${ }^{4}$ Potonji atribut, poput lokacije, izravno upućuje na povezanost objekta i zajednice jezika primatelja, kao i na njegovu globalnu važnost pa je uvršten u istraživanje. Kvantitativno se analizirala brojnost, odnosno pojavnost objekata i jezika (u apsolutnom broju) te zastupljenost, odnosno raspodjela/raširenost objekata, jezika i egzonima (u relativnom broju) u navedenim kategorijama. Rezultati će se prikazati dijagramima i kartodijagramom.

U analizama lokacije geografskih objekata i jezika izvornih imena rabe se pokazatelji »broj lokacija« i »broj jezika«. »Broj lokacija« ukupan je broj spominjanja neke vrste objekata (kontinenta/cjeline, oceana ili države) pri određivanju svih lokacija objekata te vrste. »Broj jezika« ukupan je broj spominjanja nekoga jezika pri određivanju svih jezika izvornih imena. Ukupan »broj lokacija« i »broj jezika« uvijek je veći od ukupnoga broja objekata, odnosno pripadnih egzonima (3055) jer se neki objekti smještaju u više područja, odnosno neki egzonimi imaju više izvornih imena, a time i više jezika izvornih imena. Primjerice, mnogi kopneni reljefni oblici (planinski sustavi, planinski lanci, visoravni, nizine i dr.), kopnene vode (npr. rijeke, jezera) i upravne jedinice (npr. povijesne pokrajine, regije) pružaju se u više država pa je ukupan »broj lokacija« objekata veći od ukupnoga broja objekata, odnosno egzonima. Nadalje, svi otočni oblici i objekti na dodirima različitih područja smješteni su na nekoliko kontinenata/cjelina i/ili u više oceana. Tako je ukupan »broj lokacija « kontinenata/ cjelina i oceana 3440, dok je ukupan broj geografskih objekata (i egzonima) 3055.

\section{Motrišta o uporabi egzonima}

Rasprave UNGEGN-ovih stručnjaka o uporabi egzonima u međunarodnoj i nacionalnoj komunikaciji mogu se svesti na dva oprečna stava: za i protiv uporabe

3 O bazi više u poglavlju 5.

4 Za potrebe analize zastupljenosti slovenskih egzonima, Drago Kladnik sa suradnicima koristio je 2013. iste atribute iz slovenskoga popisa. Analizu raširenosti njemačkih, mađarskih i talijanskih imena naselja u Europi napravio je Peter Jordan (2011). 
egzonima. Traju već pedesetak godina, od prvih rezolucija usvojenih na Drugoj konferenciji UN-a o standardizaciji geografskih imena 1972. (II/28, II/29), do zadnje rezolucije usvojene na osmoj konferenciji 2002. (VIII/4); s njima su upoznati i hrvatski stručnjaci. ${ }^{5}$ U rezoluciji iz 2002. upućuje se na važno obilježje egzonima, a to je da potencijalno nose teret političke nekorektnosti te da neki, osobito povijesni, izražavaju imperijalističke težnje iz doba kolonijalizma i hladnoga rata. Upravo su te moguće povijesno-političke konotacije - uz otežanu međunarodnu komunikaciju njihovom uporabom, nepotrebno opterećivanje vokabulara te postojanje nejasnoća u pisanju i uporabi egzonima (Ormeling 2012) - od samih početaka UNGEGN-a, od 1960-ih do danas, bile razlogom zašto se na egzonime gleda(lo) kao na nepoželjna imena. Negativan stav prema egzonimima bio je najizraženiji 1970-ih i 1980-h, kad ih se gotovo isključivo smatralo prisilno nametnutim imenima koja odražavaju neslavnu prošlost jezičnih ekspanzija pojedinih naroda i kolonijalizma (Woodman 2007a; Jordan 2011). Stoga se u svih osam dosad usvojenih rezolucija (URL 3; URL 4) potiče smanjenje uporabe egzonima. To zapravo znači uklanjanje egzonima iz opće uporabe i davanje prednosti endonimima.

Drugi je važan razlog kojim UNGEGN-ovi stručnjaci opravdavaju zamjenu prilagođenica izvornim imenima više pragmatičan nego ideološki. Češće se iznosi u novije vrijeme, a utemeljen je na potrebi, katkad i hitnosti, unošenja mnogobrojnih toponima na karte, u školske udžbenike i atlase, za koje ne postoje jedinstveni, usuglašeni likovi. ${ }^{6} \mathrm{U}$ nedostatku promišljenih, standardiziranih egzonima, kartografi, geodeti i geografi tada radije posežu za endonimima. Stoga su uglavnom ti stručnjaci, a tek u manjoj mjeri jezikoslovci, poticatelji osnivanja nacionalnih tijela koja bi se geografskim imenima bavila na sustavan način. Prema jezikoslovki Dunji Brozović Rončević (2011: 4) geodeti, geografi i kartografi »nisu dovoljno upoznati s povijesnim

5 Među prvim autorima koji su hrvatskoj javnosti predstavili rezolucije UNGEGN-a, implementirali ih u svoj urednički i kartografski rad te se posvetili problematici pisanja i uporabe egzonima jesu Branko Borčić, Alfonso Cvitanović i Igor Gostl. Geodet i kartograf Branko Borčić (1975) uputio je na pozitivne i negativne strane pisanja i uporabe endonima i egzonima, o čemu se raspravljalo na prvim dvjema konferencijama UN-a. Geograf Alfonso Cvitanović (1974) obrazložio je UNGEGN-ove preporuke o uporabi prilagođenica te iznio osnovne smjernice njihova pisanja i izgovora u hrvatskom jeziku. Filolog i leksikograf Igor Gostl (1985) osvrnuo se na rezolucije usvojene na prve četiri konferencije i njihovu primjenu u jugoslavenskoj kartografiji, osobito pri izradi Enciklopedije fugoslavije.

6 Kao i u drugim državama, ni u Hrvatskoj toponomastičari nisu pravodobno sustavno tretirali ni standardizirali egzonime. Prema Brozović Rončević (2011: 3): »egzonimima se dosad nije pridavala dovoljna pažnja u hrvatskom jezikoslovlju«. Ipak, većina hrvatskih pravopisa navodi znatan broj egzonima koji jesu na neki način usustavljeni. Osim toga, jednim vidom sustavnoga bavljenja egzonimima, barem dijela korpusa egzonima, možemo smatrati i prilagodbu imena iz slavenskih imena. Sustavnim, interdisciplinarnim pristupom prikupljenih egzonima iz svih jezika od 2013. bave se geografi i jezikoslovci u okviru projekta Rječnik stranih geografskih imena (URL 5), koji se provodi u Leksikografskom zavodu Miroslav Krleža. 
okolnostima i kulturnim okruženjem u kojem je nastalo pojedino ime«. Slijedi da se kao jedini obuhvatan način proučavanja i usustavljivanja egzonima nameće onaj interdisciplinarni.

Premda prevladavajući stav, praktičnost uporabe izvornih imena na račun egzonima nije jedino motrište UNGEGN-ovih stručnjaka. Egzonimi su odavno prepoznati i kao važan dio jezika zajednice primatelja te vrlo korisno sredstvo u nacionalnoj komunikaciji - iz čega se iščitavaju posve suprotne ideje, odnosno pozitivan stav prema njima. Naime, već se u prvoj rezoluciji o egzonimima (II/28) ističe činjenica da »neki egzonimi (konvencionalna imena, tradicionalna imena) tvore žive i vitalne dijelove jezika«. Takav je stav gotovo dominantan među mnogim jezikoslovcima i povjesničarima (Brozović Rončević 2011), koji egzonimima pristupaju ponajprije kao vrijednom dijelu kulturnoga nasljeđa zajednice jezika primatelja i odrednici njezina identiteta (Jordan 2009; Brozović Rončević 2011) te smatraju da se egzonimi ne mogu (i ne smiju) posve isključiti iz opće uporabe u toj zajednici. Uspoređujući dvije razine/vrste komunikacijskih kanala egzonima (međunarodnu i nacionalnu), Igor Gostl (1985: 87) primjećuje da »na razini enciklopedistike, kartografije, informatike i sl., riječju, na razini međunarodne komunikacije [egzonimi] mogu predstavljati prepreku u komunikacijskom kanalu, pa se otuda i javlja potreba za njihovim uklanjanjem ili potiskivanjem. Na kulturno-povijesnoj i obrazovnoj razini, ostaje, međutim, potreba njihova poznavanja u što širem izboru, što znači njegovanja egzonima, kako povijesnih tako i kurentnih, u okviru kulture vlastitoga jezika. Jer egzonimi su, potrebno je to izreći u naglašenom obliku, duboko ukorijenjeni u našoj svijesti i tradiciji, povijesnoj i kulturnoj baštini«. Prema istaknutom austrijskom geografu i kartografu te dobrom poznavatelju različitih jezika i jezikoslovnih pitanja Josefu Breuu (1987: 3), »svaka jezična zajednica ima pravo uporabljivati vlastite jezične resurse $u$ imenovanju svijeta koji ju okružuje, pravo koje joj ne može oduzeti ili ograničiti nikakvo vanjsko tijelo. Egzonimi su dio rječničkoga blaga jezika koji ih uporabljuje i podložni su povijesnim promjenama kao i sam jezik«.

$\mathrm{Na}$ tom su tragu i stajališta Dunje Brozović Rončević (2011), koja ističe da se egzonimi u hrvatskom jeziku javljaju u najranijoj, čak i usmenoj književnoj tradiciji, ponekad kao prve riječi stranog podrijetla koje su dobile hrvatsku inačicu. Mnogi su postali neodvojivom sastavnicom narodne tradicije te su do danas preživjeli kao dio standardnog hrvatskog jezika. Zaključuje da ih se ne može promatrati samo kao instrumente jezičnog, odnosno političkog imperijalizma (kao što je to bio slučaj u mnogim kolonijama), nego ih treba sagledavati i iz povijesne perspektive, i to kao dijelove nematerijalne kulturne baštine, tj. kao svjedoke stoljetnoga etno-lingvističkoga prožimanja. 
Egzonimi su, dakle, neodvojivi dio vokabulara svakoga jezika određene jezične zajednice te je o njima potrebno voditi brigu na jednak način kao što se vodi briga o ostalom materijalnom i nematerijalnom bogatstvu. Osim toga, upućuju na dugotrajne jezične, kulturne, političke i ekonomske veze zajednice jezika primatelja s drugim zajednicama (jezika davatelja), a oni najstariji i na dugu tradiciju prilagodbe toponima.

Poznajući složenost problematike uporabe egzonima i htijući pomiriti donekle suprotstavljena stajališta više struka, Josef Breu još 1987. obrazlaže kako se egzonime ne može promatrati jednostrano, iz rakursa jedne znanosti, odnosno naglašava važnost konteksta i svrhe uporabe egzonima. Ističe da za kartografe ne vrijede ista pravila kao za jezikoslovce. U svakodnevnoj jezičnoj komunikaciji između dvaju govornika jezika primatelja zamjena prihvaćenih egzonima izvornim imenima neprirodna je i ne treba ju poticati. S druge strane, smatra da je upisivanje pojedinih egzonima na karte stranoga područja nepoželjno jer umanjuje jezičnu ujednačenost karte.

Imajući u vidu sve navedeno, a osobito međunarodni karakter i globalnu misiju UNGEGN-a, navedena dva oprečna motrišta o uporabi egzonima (prema kartografu Ferjanu Ormelingu /2012/ tzv. međunarodni i nacionalistički pristup) vrlo su rano postala izazovom za njegove stručnjake. Naime, od prvih rezolucija uočeno je da se mišljenja o uporabi egzonima razlikuju od države do države, od jezika do jezika, ovisno o geografskim, povijesnim i jezičnim okolnostima, što se onda očitovalo u različitim praksama tretiranja egzonima. Mnoge su nacionalne kartografije post-socijalističkoga razdoblja, ne samo one svjetskih jezika, nego i one manjih istočnoeuropskih jezika, i dalje rabile egzonime, s namjerom da se $u$ uporabu vrate ranije zamijenjena tradicionalna imena (Woodman 2007a), dok su druge zemlje ustrajale na široj uporabi endonima. Bilo je stoga jasno da konačnu odluku o stupnju i dinamici uklanjanja egzonima treba prepustiti svakoj pojedinoj zemlji te da je gotovo nemoguće svugdje na jednak način implementirati preporuke UNGEGN-a.

S vremenom se sve češće propitivao tretman egzonima i rezolucije o njihovu smanjenju. Prevladavajući stav UNGEGN-ovih stručnjaka kako su oni nepotrebni i nepoželjni čak i za nacionalne potrebe (rezolucija II/29) tako je postao manje restriktivan nego na početku. Tome pripomažu promišljanja mnogih članova Radne skupine za egzonime koji su naklonjeniji egzonimima (ne svi i ne samo jezikoslovci). Oni smatraju da bi uporabu egzonima unutar zajednice jezika primatelja u određenim situacijama zapravo trebalo podupirati ili barem ne značajnije smanjivati. Objašnjavaju kako bi zamjena egzonima službenim izvornim imenima govornicima neminovno uzrokovala poteškoće u pisanju i izgovoru (Jordan 2011; Ormeling 2012). Naglašavaju i da su egzonimi nužni za imenovanje prostranih geografskih objekata koji se pružaju u više govornih područja pa imaju zajednički 
suverenitet (npr. Alpe). Uporabom samo jednog od nekoliko raspoloživih egzonima različitih jezičnih zajednica moglo bi se sugerirati da se cijeli objekt nalazi unutar jednog suvereniteta/države (Woodman 2007b), što ne samo da nije točno nego bi izazvalo polemike oko toga koji bi to suverenitet bio. Ovim se argumentima, dakako, ne osporava temeljno stajalište UNGEGN-a, prema kojem se u međunarodnoj komunikaciji trebaju rabiti endonimi (Jordan 2017a; Jordan 2017b; URL 3; URL 4).

Od 2000-ih među članovima Radne skupine naglašava se ideja o srednjem rješenju, prema kojem uporabu egzonima ne bi trebalo drastično smanjiti, nego bi ju trebalo diversificirati. To znači da bi egzonime trebalo rabiti različito, ovisno o dobnim skupinama korisnika, namjeni publikacije i vrsti komunikacije (međunarodnoj ili nacionalnoj). $S$ kartografskoga aspekta, tretman egzonima i s tim povezana uporaba na kartama uvelike ovisi o tipu i mjerilu karte te njezinoj namjeni (Breu 1987; URL 6; Ormeling 2012). Tako se najmlađim govornicima, npr. osnovnoškolcima koji moraju savladati i upamtiti mnogobrojne toponime na početku svojega školovanja pa im je to lakše s pomoću egzonima, omogućava uporaba većega broja egzonima na kartama (Jordan 2011). Zato na domaće karte valja upisivati oba imena, prvo izvorno ime, a u zagradi prilagođeno (što je u skladu s rezolucijom IV/20). Govornicima srednjoškolske dobi, u općoj i zahtjevnijoj uporabi treba ponuditi više endonima umjesto postojećih egzonima (koji se trebaju upisivati u zagradama), dok za potrebe izrade karata ili atlasa namijenjenih međunarodnom tržištu, ili primjerice u svrhu turizma (npr. atlasi i turističke karte za strane govornike), valja rabiti samo endonime. ${ }^{7}$ Što se pak dinamike smanjenja uporabe egzonima tiče, treba imati na umu da prirodne promjene jezika podrazumijevaju i promjene u uporabi egzonima pa je postupak smanjenja egzonima, ako se ne želi nasilno intervenirati u jezik, moguće ubrzati jedino postupnim uklanjanjem egzonima, i to onih neprimjerenih, kao i postavljanjem jasnih kriterija za supostojanje endonima i egzonima (rješenje koje je ionako već prihvaćeno u kartografiji).

Uzevši u obzir važeće rezolucije UNGEGN-a o smanjenju egzonima, ali i novije stavove i trendove u uporabi egzonima na nacionalnim razinama (u nekim se zemljama čak stvaraju novi egzonimi), Radna skupine pokušala je slijediti srednje rješenje te je zbog nemogućnosti normiranja jednake uporabe egzonima u svim zemljama odustala od donošenja rezolucije s jedinstvenim preporukama i 2017. donijela zaključke vezane uz globalno zajedničke karakteristike egzonima i kriterije njihove uporabe (Jordan 2017a; Jordan 2017b; Crljenko 2018). Egzonimi se obično rabe: ${ }^{8}$

7 Susljedno navedenom tretmanu egzonima, na kartama je uočeno nekoliko modela prikazivanja toponima: a) samo endonimi, b) endonimi i egzonimi u zagradama, c) samo egzonimi, d) egzonimi i endonimi u zagradama. Više o tome u: Breu 1987; Ormeling 2012; Crljenko 2019.

8 Vijeće za normu hrvatskoga standardnog jezika donijelo je 2010. slične zaključke (URL 7). 
a) prema kriterijima koji se odnose na jezik:

1. u jeziku primatelju ${ }^{9}$

2. ako se izvorno ime sastoji od specifičnoga imena i značenjski razumljive imenice ili pridjeva ${ }^{10}$

b) prema kriterijima koji se odnose na geografski objekt:

3. ako imenovani geografski objekt ima bliske i tradicionalne veze sa zajednicom jezika primatelja

4. ako je imenovani geografski objekt povijesno ili danas važan (za zajednicu jezika primatelja)

5. ako se imenovani geografski objekt prostire na više govornih područja.

\section{Popisi egzonima i UNGEGN}

U prvoj rezoluciji o egzonimima (II/28) naglašava se kako neki egzonimi, premda vitalni dijelovi jezika zajednice primatelja, ostaju u jeziku i nakon što se potreba za njima smanjila. Zato se nacionalnim tijelima zaduženima za toponime preporučuje popisivanje egzonima koji su trenutačno u uporabi, njihovo klasificiranje i izdvajanje onih neprimjerenih - ponajprije zastarjelih, netočnih, politički i kulturološki nekorektnih, ali i onih kojima se imenuju objekti unutar jedne države (rezolucija II/29) koji se što prije trebaju ukloniti. S obzirom na različitu dinamiku izrade popisa u različitim državama, a kako bi se ubrzao proces uklanjanja egzonima, preporučuje se izrada privremenih popisa s imenima samo nekih vrsta objekata (rezolucija II/35) te se sužava opis/definicija egzonima (rezolucija III/19). Prema toj definiciji toponime koje popisi ne bi trebali sadržavati su oni koji se od službenoga izvornog imena razlikuju: jer im nedostaje, dodano im je ili promijenjeno neko slovo, dijakritički znak ili član; jer im je ime promijenjeno deklinacijom; jer im je generički dio imena preveden; jer je toponim izmijenjen transkripcijom ili transliteracijom (URL 3; URL 4). Nadalje, premda su među najvećim objektima na Zemlji i unatoč činjenici da svaki jezik za njih ima svoja prilagođena imena, imena kontinenata, oceana, mora i podmorskih

9 Na primjer, kad se hrvatski govornici nalaze unutar hrvatskoga govornog područja ili kad se u Hrvatskoj objavljuju tekstovi, atlasi, kartografski ili grafički prilozi na hrvatskom jeziku namijenjeni govornicima hrvatskoga jezika.

10 Uz neke imenice i pridjeve: more, jezero, rijeka, zaljev i dr., nov, star, velik, mali, bijel, crn, gornji, donji, sjeverni, južni i dr. Na primjer, Bodensko jezero za Bodensee; Crna Volta za Volta Noire; Istočni Falkland za East Falkland; Mala Azija za Küçük Asya; Nova Gvineja za New Guinea. 
reljefnih oblika ne smatraju se egzonimima u pravom smislu riječi jer nemaju svoja izvorna imena, odnosno izvan su državnoga suvereniteta (Breu 1987; URL 6). Ipak, $i$ ta se imena navode u popisima te se analiziraju s drugim egzonimima.

Prema smjernicama za izradu popisa egzonima koje je 1991. donio Odjel za nizozemski i njemački jezik pri UNGEGN-u (URL 6) popisani egzonimi mogu se klasificirati s obzirom na nekoliko kriterija: tip/vrsta geografskoga objekta, odnos objekta i zajednice jezika primatelja, jezična obilježja egzonima, trenutna uporaba egzonima. ${ }^{11}$ Tek uzimajući u obzir navedene klasifikacije i dosadašnju praksu prilagođavanja toponima, može se pristupiti uklanjanju nekih egzonima.

Budući da se prihvaćena UNGEGN-ova definicija egzonima, prema kojoj je »egzonim ime na nekom jeziku za geografski objekt koji je smješten izvan područja toga jezika, a razlikuje se od imena na službenom ili prihvaćenom jeziku koje se rabi na području na kojem se objekt nalazi« (URL 2), s vremenom mijenjala ${ }^{12}$ te je time - ne precizirajući u kojoj se mjeri prihvaća različitost egzonima u odnosu na endonim (od jednoga do nekoliko slova u odnosu na izvorni lik, npr. Pariz za Paris ili Venecija za Venezia, do znatno ili potpuno izmijenjenoga toponima, npr. Beč ili Dunaj za Wien) te ostavljajući prostor za različite interpretacije pojma »prihvaćeni jezik«, kao i za diskusije oko potrebe unošenja »službenosti« jezika u definiciju - omogućavala različita shvaćanja pojma egzonimi, neke su države, poput Slovačke (Hajčiková i Kováčóva 1999; URL 10), Češke (Beránek et al 2006), Poljske (Zych 2013), Finske (Hakulinen, Paikkala 2013; URL 11), Slovenije (Kladnik i dr. 2013; URL 12; URL 13), izradile vrlo opširne popise egzonima. Ti su popisi međusobno sličnih struktura i atributa te ne uključuju samo one »prave«, neprijeporne egzonime određene prema suženom opisu egzonima, nego i sve one prilagođenice koje se u vrlo maloj mjeri (npr. samo u jednom slovu) razlikuju od endonima; radije su se, dakle, popisivali i oni koji nisu »pravi« egzonimi nego da ih se ispuštalo.

Osim što se u praksi pokazalo kako je zbog mnogih iznimaka vrlo teško dosljedno provoditi preporuke UNGEGN-a, dodatni razlozi obuhvatnom pristupu vođeni su željom za prikupljanjem, sistematiziranjem i očuvanjem što većega broja egzonima, za naglašavanjem duge tradicije prilagođavanja imena u svojim jezicima, a ondje gdje egzonimi nisu normirani, i stvaranjem opširne baze egzonima koja bi trebala poslužiti za klasifikaciju egzonima i njihovu standardizaciju, tj. usustavljivanje pisanja i uporabe, te uklanjanje onih neprimjerenih.

11 Više o podjelama egzonima ovisno o različitim kriterijima klasifikacije u: Crljenko 2017.

12 Na Drugoj konferenciji UN-a o standardizaciji geografskih imena 1972. predložena je prva definicija (URL 8; Breu 1987). U Glossary of terms for the Standardization of Geographical Names iz 2002. definicija je promijenjena (URL 9), a 2017. prihvaćena je današnja (URL 2). 


\section{Popis hrvatskih egzonima}

Po uzoru na slovenski popis s 5044 egzonima (Kladnik 2001, 2007; Kladnik i dr. 2013; URL 12; URL 13) izrađen je obuhvatan hrvatski popis egzonima, koji je djelomično objavljen u priručniku Hrvatski egzonimi II. (Crljenko 2018), a potom je proširen i dopunjen za potrebe mrežnoga izdanja Hrvatskih egzonima (u pripremi). U njemu su zbog poteškoća razdvajanja pojedinih kategorija zajedno popisani: a) suvremeni (tzv. kurentni; prema Gostl 1985) egzonimi, koji se rabe svakodnevno; b) povijesni egzonimi (tzv. arhaični, prema Gostl 1985), koji se ne rabe svakodnevno, ali imaju književno-povijesnu vrijednost (mnogi su povijesni egzonimi danas zastarjeli); c) egzonimi u nestajanju (prema Harvalík 2016), koji se još uvijek rabe u pojedinim izvorima ili strukama, najčešće kao alternativna imena (npr. Carigrad). Ugrubo, manje je od $10 \%$ povijesnih egzonima.

Kriteriji odabira hrvatskih egzonima uvrštenih u popis jesu sljedeći: a) ime treba biti prilagođeno hrvatskom jeziku, što znači da se u najmanjoj mogućoj mjeri razlikuje od izvornoga (izvornih) imena, makar u jednom slovu; b) od izvornog (izvornih) imena treba se razlikovati u barem jednom službenom jeziku; c) treba biti potvrđeno u najmanje dvama izvorima, što znači da se tražilo minimalno potvrđivanje prilagodbe imena; d) može biti povijesna i/ili zastarjela prilagođenica.

U izradi popisa hrvatskih egzonima korišteno je 25 izvora nastalih u razdoblju od 130 godina, tj. od prvoga obuhvatnijega prijevodnog atlasa na hrvatskom jeziku iz 1887. do 2018. Uz atlase svijeta, u kojima je najviše egzonima, pregledani su i drugi izvori - geografske monografije, mrežne enciklopedije, rječnici, leksikoni i službeni popisi imena. Međutim, egzonimi nisu samo popisani. Oni su i opisani i to s različitim brojem atributa ovisno o objektu koji imenuju (uz imena država je 40 atributa, uz imena glavnih gradova 35 atributa, uz imena ovisnih područja 34 , uz imena ostalih objekata 27 atributa). Tako je nastala vrlo opsežna baza s 3055 preporučenih hrvatskih egzonima s pripadnim atributima, ${ }^{13}$ koja je poslužila kao temelj kvantitativne obrade podataka za ovo istraživanje. Brojnost egzonima, potvrđenost likova u mnogim izvorima i ustaljenost likova većine popisanih egzonima upućuju na pozitivan odnos hrvatskih govornika prema egzonimima i dugu tradiciju prilagodbe toponima u hrvatskom jeziku.

13 Popis izvora objavljen je u priručniku Hrvatski egzonimi II (Crljenko 2018). U njemu su i opisi većine atributa. Objašnjenja svih 40 atributa bit će dostupna na web stranici mrežnoga izdanja Hrvatskih egzonima. 


\section{Hrvatski egzonimi prema tipu geografskoga objekta}

Jedna od najčešćih podjela toponima, a onda posredno i egzonima, među hrvatskim i stranim jezikoslovcima, geografima i kartografima ${ }^{14}$ klasifikacija je prema tipu geografskoga objekta koji imenuju pa toponimi mogu biti: oronimi, hidronimi, ojkonimi, horonimi, hodonimi i dr. Činjenica zapravo ne treba čuditi jer je takva podjela vjerojatno najočitija, najlogičnija i najjednostavnija podjela toponima/egzonima. Prvo se, naime, pitamo na što se ime odnosi, na rijeku, planinu, naselje, more, državu. S obzirom na brojnost geografskih objekata i različitost njihovih obilježja, objekti se na početnoj, osnovnoj razini mogu podijeliti na prirodne i društvene. Daljnjim klasificiranjem na temelju skupine zajedničkih obilježja dobivaju se različiti tipovi, a još detaljnije i podtipovi objekata.

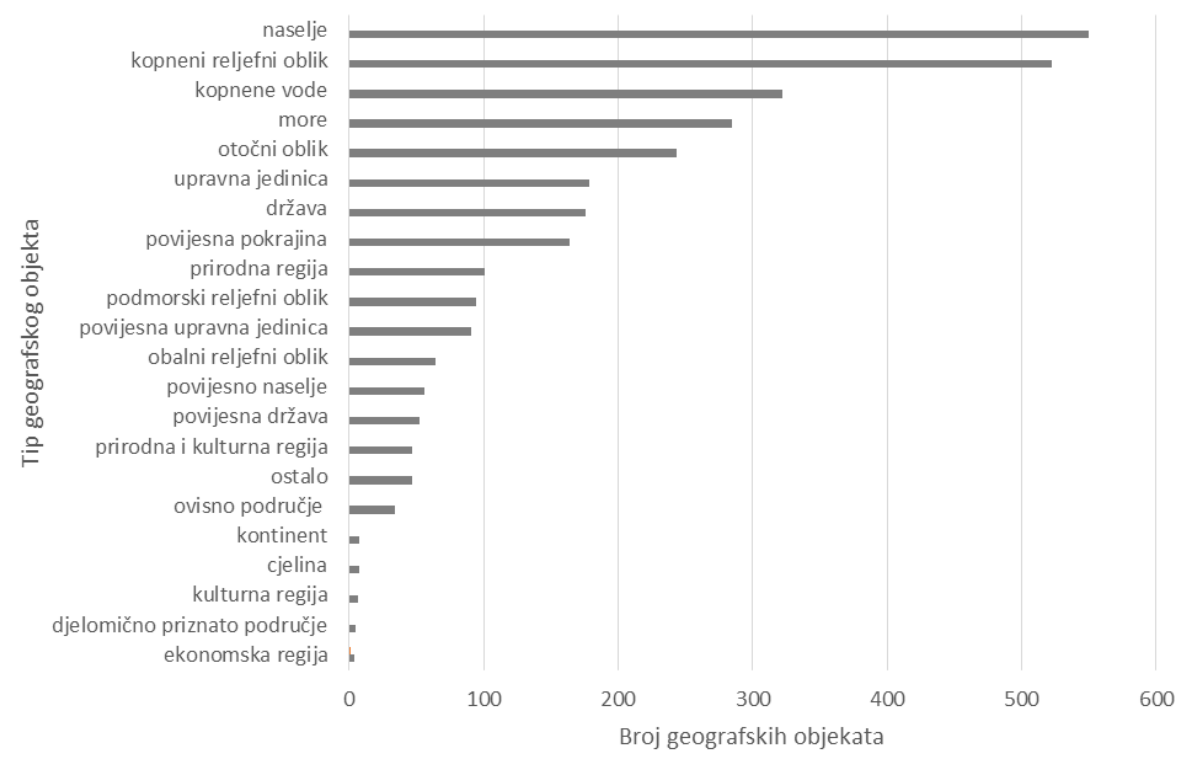

Slika 1. Hrvatski egzonimi prema tipu geografskoga objekta

Svi geografski objekti zabilježeni u popisu/bazi hrvatskih egzonima mogu se uvrstiti u neki od 22 izdvojena tipa, npr. naselje, kopneni reljefni oblik, kopnene vode, more, otočni oblik i dr. (slika 1.), od kojih se mnogi dalje dijele na podtipove. Primjerice, kopneni reljefni oblici mogu biti: planinski lanci, gorja, nizine, visoravni, sredo-

14 Neki hrvatski istraživači su: Pavle Rogić, Petar Šimunović, Vladimir Skračić, Radovan Pavić, Paško Lovrić. Među stranima su: Josef Breu, Drago Kladnik, Donald J. Orth. Više o tome u: Crljenko 2017. Klasifikacijama egzonima bave se i članovi Radne skupine za egzonime, koji su svoje radove na tu temu objavili u zborniku The Classification of Exonyms (Dollimore i Watanabe 2019). 
gorja, zavale, kotline, brda, špilje, jame i dr.; kopnene vode su: jezera, močvare, rijeke, riječni kanali i dr.; upravne jedinice mogu biti: savezne države, republike, pokrajine, departmani, županije i dr. ${ }^{15}$ Detaljnije se analiziraju tipovi s više od 200 objekata.

Analiza hrvatskih egzonima prema tipu geografskoga objekta pokazuje da ih se najviše, 550 egzonima (18,0\%), odnosi na naselja. Podatak govori u prilog činjenici da su naselja najvažnije društveno konstruirane jedinice geografskoga prostora, tj. organizirana su okupljališta ljudi, djelatnosti, kulture i ljudskoga života uopće, pa se zbog toga češće od drugih prostornih jedinica upisuju u opće geografske karte, odnosno u tekstove odabranih izvora, bez obzira na inačicu kojom su imenovani (egzonim ili endonim). Sukladno tomu, prirodno je očekivati i više egzonima za naselja nego za druge objekte. Međutim, njihov najveći udio u ukupnom broju egzonima upućuje i na to da su mnoga naselja tijekom vremena dobila svoje prilagođenice upravo zbog svoje važnosti za hrvatske govornike, a ne samo zbog opće brojnosti imena naselja.

Po brojnosti slijede kopneni reljefni oblici, koji su zastupljeni sa 17,1\%, kopnene vode s $10,5 \%$, mora s $9,3 \%$, a otočni oblici s $8,0 \%$. Svaki od ostalih tipova objekata u popisu se pojavljuje manje od 200 puta, tj. manje od $6,0 \%$. I kopneni reljefni oblici su, poput imena naselja, među najbrojnijim elementima topografskih (općih geografskih) karata. Mnogi objekti svrstani u najbrojnije tipove uglavnom su veoma prostrani, a s tim povezano najčešće i globalno važni (npr. planinski sustavi, planinski lanci, gorja, visoravni, otoci, rijeke, jezera, države). Među najvećima su i oni koji imaju prekogranični karakter, što znači da se često protežu i na više govornih područja (npr. Alpe, Dunav, Gornje jezero, Gvajansko gorje, Himalaja, Kaspijsko jezero, Rajna).

Povezanost između zastupljenosti egzonima i veličine, tj. prostiranja objekta može se pokazati na primjeru kopnenih reljefnih oblika. Premda je bez uvida u veličinu svakog pojedinog objekta nezahvalno donositi tvrdnje o navedenom odnosu, ugrubo se može reći da je gotovo $80 \%$ objekata koji pripadaju različitim podtipovima kopnenih reljefnih oblika veliko, odnosno prostrano. Uz kontinente i cjeline, oceane i mora, podmorske zavale i hrptove, najveće otoke i jezera te najdulje rijeke, u ovu se skupinu, naime, ubrajaju neki od najvećih objekata na Zemlji: planinski sustavi (npr. Alpe, Ande, Apalačko gorje, Himalaja, Hindukuš, Karpati, Pireneji, Stjenjak), planinski lanci (npr. Andaluzijsko gorje, Elburs, Istočni Gati, Južni Karpati, Obalno gorje, Saharski Atlas, Ural), planinske skupine (npr. Bavarske Alpe, Istočne Alpe, Katalonsko gorje, Niske Ture), gorja (npr. Čukotsko gorje, Hangaj, Jura, Kambrijsko

15 Temeljni popis tipova (19) s pripadnim podtipovima koji se u manjoj mjeri doradio za potrebe ove analize nalazi se u priručniku Hrvatski egzonimi II. (Crljenko 2018: 16-17). Sličnu su podjelu napravili Kladnik i dr. (2013). 
gorje, Peninsko gorje), nizine (npr. Hindustanska nizina, Istočnoeuropska nizina, Panonska nizina, Sjevernonjemačka nizina, Vlaška nizina), visoravni/visočja (npr. Anatolska visoravan, Brazilsko visočje, Gvinejsko visočje, Meksička visoravan, Srednjosibirsko visočje), zavale (npr. Amazonska zavala, Čadska zavala, Sečuanska zavala), poluotoci (npr. Anatolija, Arapski poluotok, Koreja, Labrador, Mala Azija) i dr. Ostali objekti (oko $20 \%$ ) veličinom se mogu svrstati u srednje i manje objekte (planine, vulkani, prijevoji, kotline, pobrđa, brežuljci, vrhovi i dr.). Neki od njih, premda maleni, prometno, trgovinski ili životno iznimno su važni pa zato imaju svoju prilagođenicu (npr. Brennerski prijevoj, Korintska prevlaka, Vezuv).

Jednak suodnos između zastupljenosti egzonima i veličine geografskoga objekta uočava se i u egzonima kopnenih voda, mora, otočnih oblika, podmorskih reljefnih oblika, regija, povijesnih država i pokrajina i dr. Egzonimi rijeka zastupljeni su s $54,7 \%$ svih egzonima kopnenih voda. Svoje suvremene ili povijesne prilagođenice imaju one najdulje i najvažnije rijeke (npr. Eufrat, Ganges, Ind, Jenisej, Jordan, Majna, Mekong, Nil, Pad, Rajna, Sir-Darja, Temza). Udio imena jezera u imenima kopnenih voda je $31,4 \%$. Među njima su oni najvećih i najvažnijih svjetskih jezera (npr. Aralsko jezero, Bajkalsko jezero, Blatno jezero, Čadsko jezero, Gornje jezero, Kaspijsko jezero, Ladoško jezero). Premda prostorno maleni objekti, riječni kanali važni su prometni putovi pa imaju hrvatske egzonime (npr. Kanal Rajna-MajnaDunav /zapravo je plovni put/, Kielski kanal).

Geografska imena vezana uz morske prostore dobar su primjer suodnosa zastupljenosti egzonima i važnosti objekta. Ta su se imena odavno prilagođavala hrvatskom jeziku ponajprije zbog naše duge tradicije plovidbe svjetskim morima (time i poznavanja morskih objekata), dugotrajnoga globalnog iskorištavanja mora i podmorja te značenja koje pomorstvo ima u svjetskom i hrvatskom gospodarstvu (značenje nije uvijek povezano s veličinom objekta pa mnogi manji, ali prometno važni zaljevi i prolazi imaju svoje egzonime), katkad jednostavno i zbog veličine objekta te činjenice da neki od njih (oceani, mora i prostrani zaljevi) ne pripadaju niti jednom suverenitetu pa imaju egzonime na svim jezicima. U ukupnom broju imena morskih prostora najviše je imena zaljeva (48,1\%; npr. Bengalski zaljev, Biskajski zaljev, Botnijski zaljev, Gvinejski zaljev, Meksički zaljev, Tršćanski zaljev), prolaza (26,7\%; npr. Bab el Mandeb, Beringov prolaz, Bospor, Dardaneli) i mora (22,8\%; gotovo sva mora, osim nekih manjih u Tihom oceanu, imaju svoje ime u hrvatskom jeziku). Premda zastupljeni s najmanjim udjelima u morskim prostorima, svi oceani i tri važna morska prolaza (Korintski, Panamski i Sueski kanal) imaju svoje prilagođenice.

Kao rezultat opće važnosti i specifičnosti otočnih zajednica, hrvatske su prilagođenice dodjeljivane i mnogim otocima i otočnim skupinama, osobito najvećima (npr. Grenland, Hokaido, Java, Nova Gvineja), često i geografski najbližima (npr. Korzika, Kreta, Krf, Lefkada, Sicilija), odnosno najprostranijim i/ili bližim skupina- 
ma otoka (npr. Antili, Baleari, Cikladi, Jonski otoci, Lofoti, Privjetrinski otoci, Vanjski Hebridi). Od svih otočnih oblika koji imaju svoj egzonim, pojedinačni otoci i otočne skupine zajedno čine $96,7 \%$ (ostalo su atoli, riječni i jezerski otoci i koraljni grebeni).

Zaključno se može reći da je u svim tipovima objekata uočen sljedeći model prilagođavanja imena: što je geografski objekt veći, globalno (ali i nama) ekonomski (osobito prometno i trgovinski), politički, kulturno i povijesno važniji te smještajno bliži, veća je vjerojatnost da će imati hrvatski egzonim. To je samo potvrda ustaljene uporabe egzonima ovisno o (pod)tipu geografskoga objekta (Breu 1987; Crljenko, Klemenčić 2011; Ormeling 2012; Crljenko 2018). U praksi, egzonimi se rabe za:

1. sve kontinente, veće prirodne i kulturne cjeline, oceane, države i povijesne države.

Za sve ostale objekte nema pravila, što znači da se egzonimi katkad rabe u većoj, a katkad u manjoj mjeri. Ipak, uobičajeno se rabe:

2. za većinu mora i ovisnih područja

3. za mnoge prirodne regije i povijesne pokrajine, savezne države, upravne jedinice, otoke i skupine otoka

4. za neke danas ili povijesno važnije, osobito veće i prekogranične, kopnene, obalne i podmorske reljefne oblike te kopnene vode i ostale objekte

5. za samo neka naselja, i to uglavnom za ona koja su zajednici jezika primatelja povijesno važna (npr. glavni i važniji gradovi, veće luke, poprišta bitki, arheološka nalazišta).

\section{Hrvatski egzonimi prema lokaciji geografskoga objekta}

Prema lokaciji geografskoga objekata, hrvatski egzonimi analiziraju se u četiri kategorije, tj. lokacije: a) na kontinentu, b) u oceanu, c) u državi, d) u moru. Posve logično, očekuje se da zastupljenost egzonima ovisi o udaljenosti objekata, i to slijedeći pravilo: što je geografski objekt smješten bliže hrvatskim govornicima, veća je vjerojatnost da ima bliske i tradicionalne veze s nama, a time i hrvatsku prilagođenicu. Tu je pretpostavku iznio i filolog Marko Kovačić (2019), koji smatra kako se već pogledom na kartu može pretpostaviti gdje treba očekivati egzonime. Po njegovu mišljenju, zajednica jezika primatelja za svoje susjedne zajednice jezika davatelja ima prilagođena imena, a za manje i udaljene objekte nema svoje već se služi izvornim imenima (za udaljene objekte) ili posredničkim imenima (za najudaljenije objekte). Kako tvrdi, govornici nisu skloni prilagođavati toponime na svoj jezik ako rezultat previše odudara od endonima (što u hrvatskih govornika može biti slučaj s toponimima iz nama udaljenih jezika, odnosno dalekih objekata, pa ih stoga nemamo mnogo op.a.). 
Određivanje lokacije geografskoga objekta ponajprije ovisi o njegovu tipu, odnosno podtipu. ${ }^{16}$ Tako je za sve kopnene objekte određen smještaj na kontinentu i u državi kojoj danas pripada, odnosno državama koje obuhvaća. Mora i dijelovi mora pripadaju oceanima i pripadajućim morima. Obalni reljefni oblici koje ispunjava voda leže unutar kontinenta, oceana, države i mora, a oni koji su dijelovi kopna leže na kontinentu i u državi. Podmorski reljefni oblici locirani su unutar oceana i mora. Otočni oblici leže u moru/morima i oceanu, kao i na kontinentu i u državi/državama kojima pripadaju. Budući da su ovisna područja većinom otočni oblici, lokacija im je određena kao i drugim otočnim oblicima. Nerijetko je zbog svega navedenog »broj lokacija« veći od broja objekata, odnosno pripadnih egzonima (vidi poglavlje 2).

\section{Kontinenti/cjeline i države}

Najviše geografskih objekata s hrvatskim egzonimima nalazi se na kontinentu kojem pripadamo (Europi s 1299 lokacija, što je 46,7\% ukupnoga broja lokacija) ili na kontinentima koji su nam bliže (Aziji s 26,4\% i Africi s 11,7\% lokacija). S druge pak strane, udaljena se Australija kao lokacija nekoga objekta s hrvatskim egzonimom pojavljuje tek 37 puta (1,3\%), a Južna Amerika 61 put (2,2\%) (slika 2.).

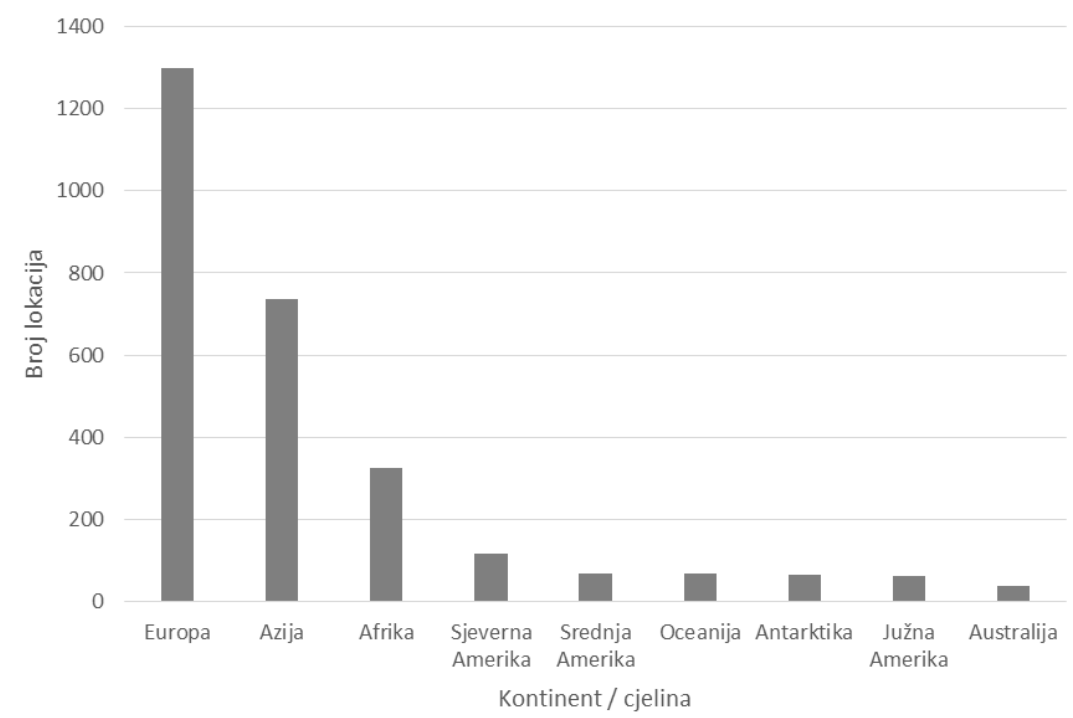

Slika 2. Hrvatski egzonimi prema lokaciji geografskoga objekta (kontinenti i cjelina) 2018).

${ }_{16}$ Određivanje lokacije geografskoga objekta preuzeto je iz Hrvatskih egzonima II. (Crljenko 
Očito je da na takvu raspodjelu hrvatskih egzonima više utjecala pripadnost (Europa) i blizina kontinenata (Azija, Afrika), odnosno jake tradicionalne veze s europskim državama, nego povezanost hrvatske zajednice s prekomorskim zemljama u Sjevernoj Americi, Južnoj Americi i Australiji. Dakako, važan je i utjecaj jezika izvornih imena (koji su nam u slučaju udaljenih kontinenata poznati pa njihove endonime možemo lako pisati i ne trebamo stvarati egzonime), vrijeme i način nastanka egzonima te slabija poznatost i manja važnost udaljenih objekata, primjerice u Australiji i Oceaniji.

Navedeni čimbenici koji utječu na zastupljenost hrvatskih egzonima u određenim područjima - oni geografski (udaljenost i veličina objekta te njegova važnost na globalnoj razini), kulturno-povijesni (različite veze i dodiri između dviju zajednica) i jezični (poznatost i bliskost jezika zajednice davatelja) - još se bolje uočavaju u analizi zastupljenosti hrvatskih egzonima po državama na primjeru Europe. Kako je prikazano na slici 3. i slici 4., najviše objekata s hrvatskim egzonimima locirano je u Grčkoj (163 ili 9,8\% u odnosu na sve zabilježene lokacije), potom u Rusiji (128 ili 7,7\%), Italiji (124 ili 7,5\%) i Njemačkoj (122 ili 7,5\%).

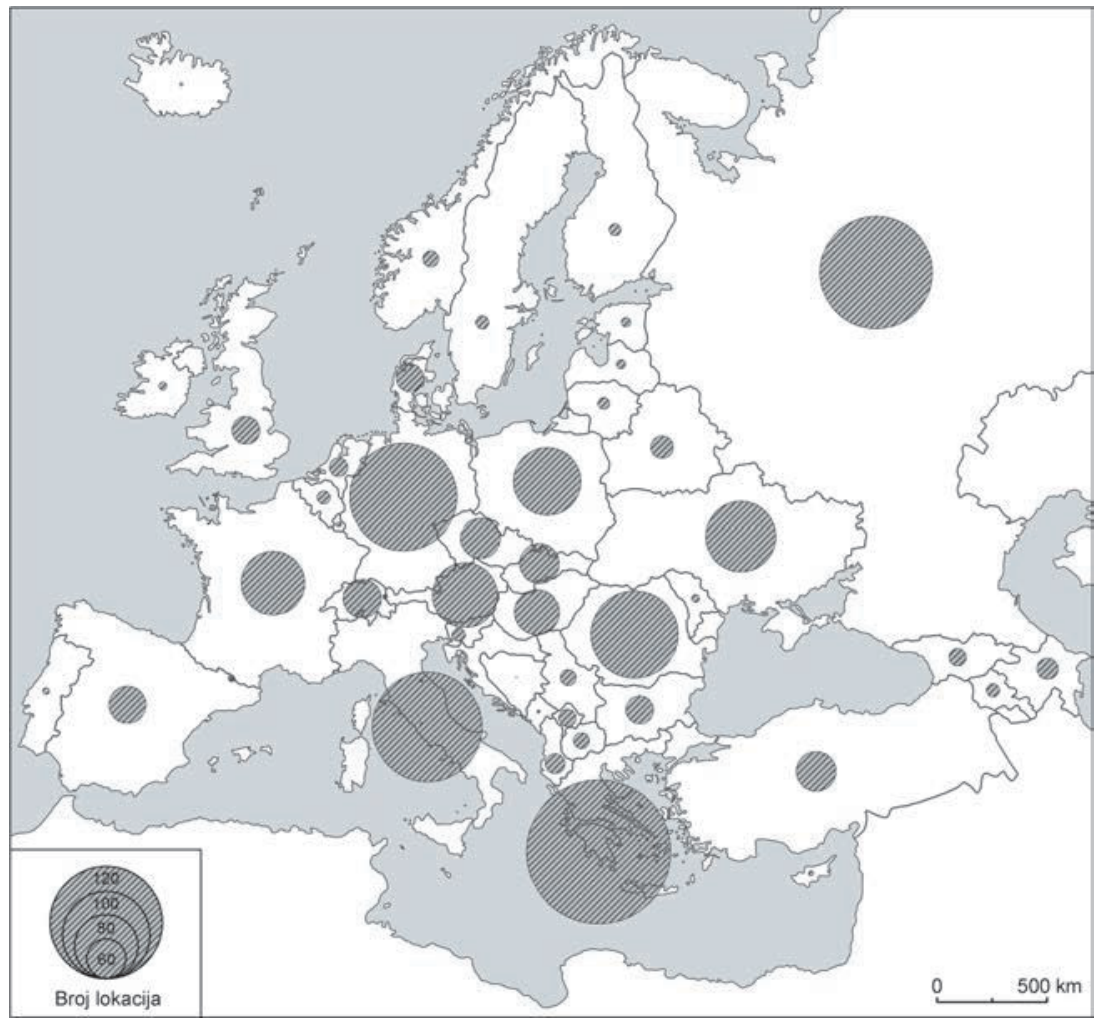

Slika 3. Zastupljenost hrvatskih egzonima u europskim državama 
Kad im pribrojimo države s više od 30 lokacija, tj. 2,0\% (slika 4.), očito je da je najviše hrvatskih egzonima u državama koje su: a) nam geografski bliže pa smo s njima dijelili davnu ili suvremenu povijest (npr. Italija, Austrija, Mađarska, Češka, Slovačka, Rumunjska, Njemačka); b) ili su to površinom velike, mnogoljudne, danas i/ili u prošlosti globalno ekonomski, politički i kulturno utjecajne europske države (npr. Njemačka, Francuska, Španjolska, Rusija, Ujedinjeno Kraljevstvo, Grčka, Turska); c) ili su to države s bliskim nam, slavenskim jezicima, iz kojih smo izravno ili pod utjecajem kojih jezika smo stvorili svoje egzonime (npr. Rusija, Ukrajina, Poljska).

Susljedno tomu, ne čudi činjenica da je manje od 20 lokacija zabilježeno u geografski, kulturno, jezično i povijesno udaljenim državama, poput Finske, Švedske, Norveške, Estonije, Litve, Latvije, Belgije, Nizozemske, Armenije, Gruzije i Azerbajdžana, a manje od deset lokacija, ako zanemarimo patuljaste države poput Vatikana, San Marina, Monaka, Lihtenštajna i Andore, u onima koje su uz veće geografske udaljenosti i slabije kulturno-povijesne veze još i površinom i stanovništvom malene ili općenito slabije utjecajne države (Malta, Island, Cipar, Luksemburg, Portugal, Irska i Moldavija).

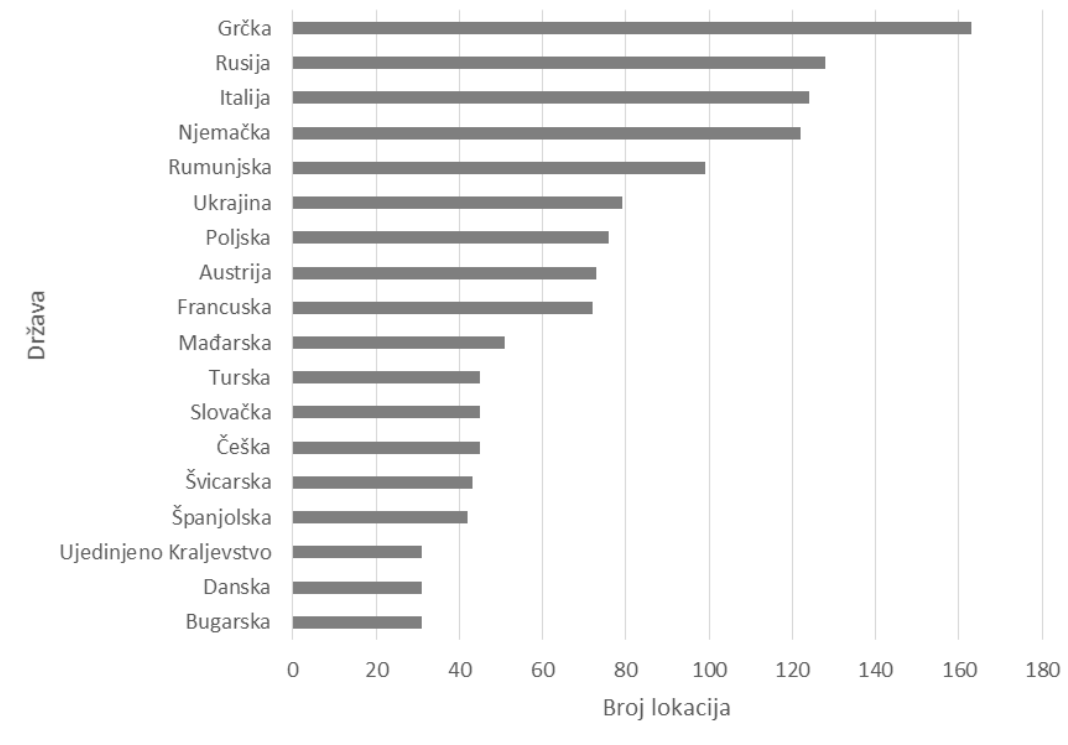

Slika 4. Hrvatski egzonimi u europskim državama (broj lokacija > 30)

Što se ostalih kontinenata tiče, najviše je hrvatskih egzonima u Aziji za objekte smještene u Kini (96 lokacija), Indiji (62) i Iranu (60). U Africi smo, očekivano, najviše toponima prilagodili u sjevernim državama: u Egiptu, Sudanu, Libiji, Alžiru i Ma- 
roku, a u Amerikama mnogo više u Sjedinjenim Američkim Državama i Kanadi (više od 40 u svakoj) nego u južnoameričkim državama (do 20; najviše u Kolumbiji, Venezueli i Ekvadoru). U Australiji su zabilježene 33 lokacije, dok smo u državama Oceanije prilagodili tek pokoji toponim, najčešće ime države, glavnoga grada, važnije skupine otoka, mora i morskoga prolaza.

\section{Oceani i mora}

Svi geografski čimbenici koji utječu na raspodjelu hrvatskih egzonima na kontinentima i cjelinama vrijede i za oceane i mora. Vjerojatno najveći utjecaj na prilagodbu imena mora, zaljeva, prolaza, kanala, podmorskih i nekih obalnih reljefnih oblika, otoka, otočnih skupina i otočnih ovisnih područja imaju čimbenici udaljenosti i važnosti objekta. Kulturno-povijesni i jezični čimbenici - koji se odnose na veze između dviju jezičnih zajednica i obilježja jezika izvornog imena - ne mogu utjecati na prilagodbu imena nekih podtipova objekata (npr. oceana, mora, prostranih zaljeva, podmorskih reljefnih oblika) jer ne postoji zajednica jezika davatelja imena pa nema ni njihova izvornog imena. Potonji čimbenici utječu na prilagodbu imena morskih prolaza i kanala, manjih zaljeva, obalnih reljefnih oblika, otoka, skupina otoka i otočnih ovisnih područja.

Za većinu prilagođenica ove skupine vrijedi opće pravilo: što je udaljenost geografskoga objekta od hrvatskih govornika manja, a njegova površina i globalna važnost veća (najčešće u pomorstvu), veća je vjerojatnost postojanja hrvatskoga egzonima. Logično je stoga da je najviše objekata s hrvatskim egzonimima locirano $u$ najbližem nam Atlantskom oceanu (254 ili 38,4\% ukupnoga broja lokacija), i to u njegovu najprometnijem, sjevernom dijelu (218 ili $86 \%$ od svih lokacija), kao i u najvećem oceanu, Tihom oceanu (192 ili 29,0\%). U udaljenijim i slabije prometnim oceanima (Indijskom, Arktičkom i Južnom oceanu) zastupljenost hrvatskih egzonima opada (slika 5.)

U odnosu na sva svjetska mora, najviše hrvatskih egzonima bilježi se za objekte smještene u Sredozemnom moru (79 ili 28,4\% ukupnoga broja lokacija) (slika 6.). Najčešće imenuju otoke, otočne skupine i morske zaljeve u Egejskom moru (20), a potom u Jonskom moru (12). U Karipskom se moru nalazi 40 objekata s hrvatskim egzonimima, a u Baltičkom 20. U udaljenim morima taj je broj daleko manji (npr. u Škotskom moru 1, Botnijskom zaljevu 2, Baffinovom, Gvinejskom i Meksičkom zaljevu po 3, Sargaškom moru 4, a Labradorskom, Norveškom i Hebridskom moru po 5). 
Studia lexicographica, 14(2020) 26, STR. 37-63

Ivana Crljenko: Analiza uporabe hrvatskih egzonima s obzirom na obilježja geografskoga objekta

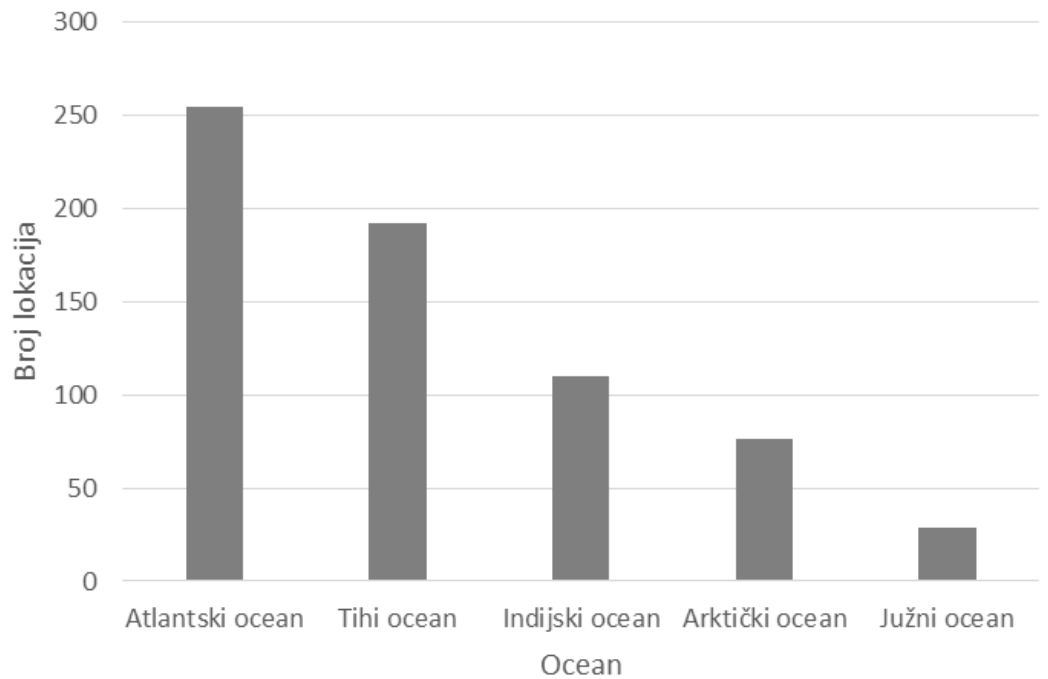

Slika 5. Hrvatski egzonimi prema lokaciji geografskoga objekta (oceani)

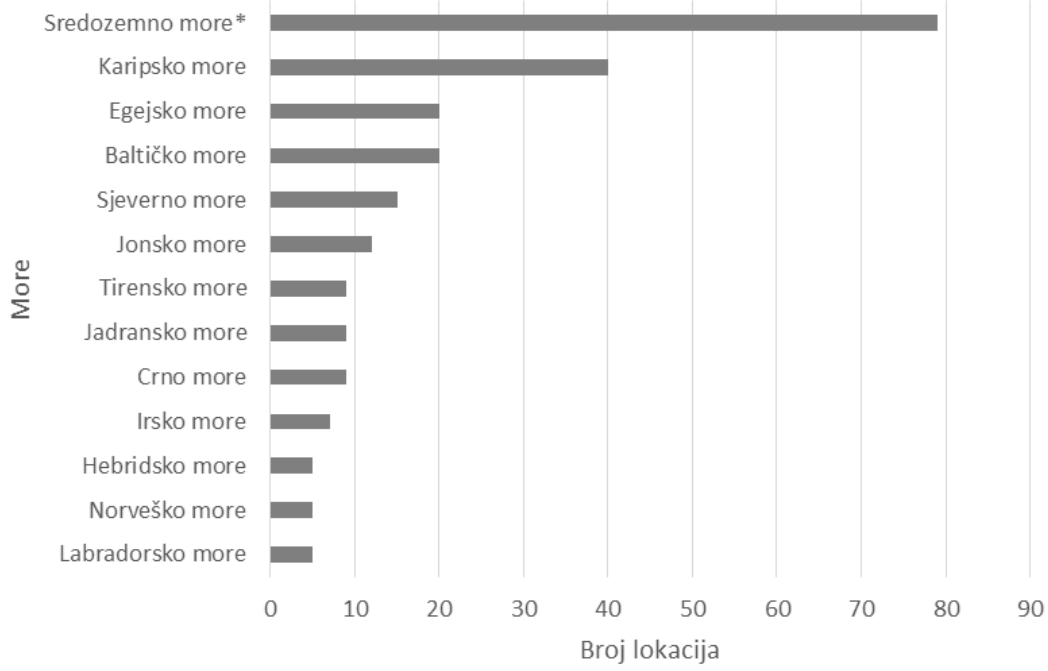

Slika 6. Geografski objekti u Atlantskom oceanu (broj lokacija $>5$ )

* U Sredozemno more ubrajaju se: Alboransko, Azovsko, Balearsko, Crno, Egejsko, Jadransko, Jonsko, Levantsko, Ligursko, Mramorno i Tirensko more 
Što se ostalih oceana tiče, najviše se hrvatskih egzonima veže uz Tihi ocean, i to uz objekte smještene u Južnokineskom moru (23 lokacije), Koraljnom moru (14), Javanskom moru (13) te Japanskom (Istočnom moru; 10) i Ohotskom moru (10). U Indijskom oceanu najviše se hrvatskih egzonima odnosi na objekte u Andamanskom moru (18 lokacija), Bengalskom zaljevu (15) i Arapskom moru (14). S povećanjem udaljenosti i slabije poznatosti prostora i jezika, smanjuje se broj hrvatskih egzonima u najsjevernijem i najjužnijem oceanu. Tako se samo dva mora Arktičkoga oceana ističu po nešto većem broju hrvatskih prilagođenica: Barentsovo more (16) i Karsko more (15). Uz sva mora Južnoga oceana veže se manje od pet hrvatskih egzonima.

\section{Hrvatski egzonimi prema jeziku izvornoga imena}

Uz izvorna imena suvremenih prilagođenica, u bazi su se popisivali službeni jezici, rjeđe i govorni (ako su pronađeni pouzdani latinični likovi), a uz povijesne prilagođenice i povijesne objekte (npr. povijesna naselja, pokrajine, države) zabilježen je barem jedan jezik iz kojega je nastala prilagođenica (koji danas ne mora biti služben ili raširen, ili se njime uopće više ne govori). ${ }^{17} \mathrm{Na}$ primjer, uz ime povijesne države prilagođenog imena Abesinija upisan je latinski jezik jer endonim Abyssinia potječe iz latinskoga jezika; uz današnje tursko naselje Aleksandretu upisani su grčki i latinski jezik jer smo prilagođenicu stvorili iz tih dvaju jezika. Zbog navedenog, i ovdje je »broj« veći od broja objekata, odnosno pripadnih egzonima (vidi poglavlje 2). Ovisno o jeziku izvornoga imena, hrvatski egzonimi prilagođeni su iz 143 jezika, od kojih su najzastupljeniji prikazani na slici 7 .

Posve očekivano, najbrojniji su hrvatski egzonimi koji su nastali iz najraširenijih, često posredničkih svjetskih jezika, engleskoga (816 ili 16,8\% ukupnoga broja jezika), francuskoga (354 ili 7,3\%), ruskoga (339 ili 7,0\%) i arapskoga jezika (302 ili $6,2 \%$ ). Osim četiriju navedenih službenih jezika UN-a, preostala dva, kineski i španjolski, ukupno se u popisu pojavljuju 277 puta. Više od 200 puta pobrojeni su njemački (282 ili 5,8\%) i grčki jezik (277 ili 5,7\%).

Prevlast engleskoga jezika kao izvornoga jezika mnogih hrvatskih prilagođenica ne začuđuje s obzirom na to da je to globalno najširi (kolonijalni) jezik, a zbog toga i najvažniji jezik posrednik u mnogim jezicima, tako i u hrvatskom jeziku. Glavni razlog takve zastupljenosti jest činjenica da je u mnogim državama, primjerice u bivšim britanskim kolonijama poput Bahama, Indije, Mjanmara, Salomonovih Otoka, Sejšela, Zambije, on danas jedan od ili jedini službeni jezik (u mnogima je vrlo raširen premda nije službeni). Budući da je zbog velikih udaljenosti većina tih objekata (npr. otočnih skupina koje su nekoć bile kolonije) nama slabo poznata, do nas su, ali i u druge europske države, njihova imena često pristizala upravo u engleskoj (po-

\footnotetext{
17 Određivanje jezika izvornoga imena preuzeto je iz Hrvatskih egzonima II. (Crljenko 2018).
} 


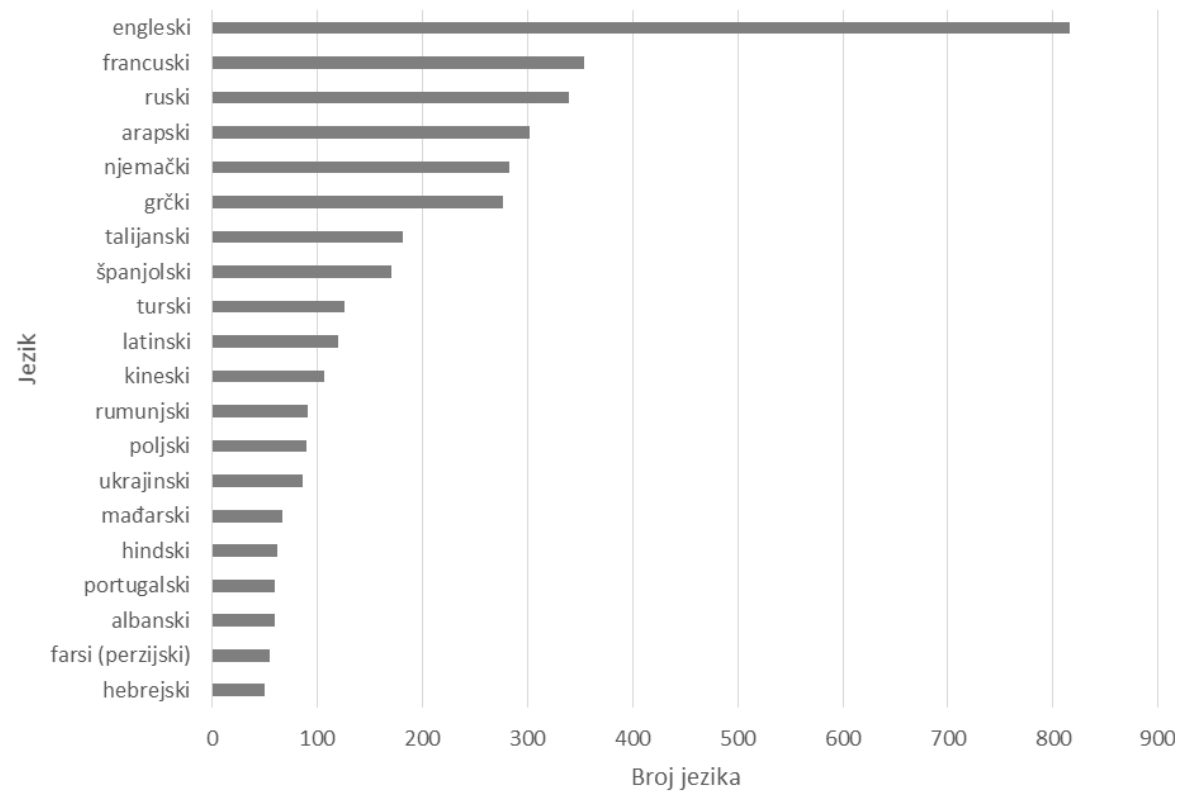

Slika 7. Hrvatski egzonimi prema izvornim jezicima (broj jezika > 50)

sredničkoj) inačici, pa smo ih, poput drugih europskih naroda, ili izravno preuzimali iz engleskoga (npr. Grenada, Nauru) ili smo ih prilagođavali iz engleske, a ne starosjedilačke inačice. Ime na starosjedilačkom jeziku ili nismo poznavali ili nam je jezično bilo odveć daleko (npr. Novi Zeland smo prilagodili prema engleskom New Zealand, a ne prema maorskom Aotearoa).

Utjecaj engleskoga jezika ne očituje se samo u njegovoj posredničkoj ulozi u stvaranju drugih egzonima - ulozi koja je nekada bila mnogo veća nego danas - nego i u činjenici da je to službeni jezik u mnogim zemljama, od kojih su neke među najvećima u svijetu (Sjedinjene Američke Države, Kanada). Također, njegov se utjecaj, ne nužno kao jezika posrednika u stvaranju hrvatskih egzonima, očituje i u zastupljenosti engleskih egzonima u mnogim nacionalnim atlasima, tako i hrvatskim, koje izrađuju autori i urednici izvan engleskoga govornog područja. U njima se mogu pronaći engleski egzonimi kad to nije potrebno, tj. kad je objekt moguće obilježiti vlastitim egzonimom (jer on postoji) ili pak endonimom (što je korektnije od uporabe engleskoga egzonima). Prema Marku Kovačiću (2019), važnost Ujedinjenog Kraljevstva, Sjedinjenih Američkih Država i engleskoga jezika očituje se u rasprostranjenosti engleskih toponima (a time i engleske grafije) svugdje po svijetu. Povezuje to s globalnim procesima i djelatnostima (trgovina, turizam, promet, tehnologija) u snažno povezanom suvremenom svijetu u kojima engleski jezik ima vodeću 
ulogu. Treba ipak naglasiti da prodiranje engleskoga jezika u toponimije drugih zemalja u novije doba uglavnom ne stvara nove engleske toponime posrednike $u$ drugim jezicima, tako ni u hrvatskom jeziku. Može tek doći do nesmotrenoga doslovnog preuzimanja engleskih imena kakvo je opaženo u nekim našim atlasima. Sukladno UNGEGN-ovim preporukama, naime, sve se češće na račun egzonima rabe suvremeni endonimi i pretkolonijalna starosjedilačka imena.

Francuski je drugi važan posrednički jezik, koji se govori »u bivšim francuskim i belgijskim kolonijama, pogotovo u Quebecu i zapadnoj i srednjoj Africi, a tome se mogu pridodati i kreolski jezici utemeljeni na francuskom. Francuski jezik samo je posrednik između mnogih berberskih, arapskih i drugih afričkih toponima s jedne strane i europskih jezika s druge« (Kovačić 2019: 187). Stoga su obilježja geografskih objekata (udaljenost, veličina, važnost, poznatost) te mehanizmi i trajanje posredništva između starosjedilačkih endonima i hrvatskih prilagođenica preko francuskoga isti kao u engleskom jeziku. Na primjer, iz francuskoga smo preuzeli imena alžirskoga grada Orana (arapski Wahrān), prilagodili smo imena gradova Alžira (francuski Alger, arapski Al-Ğazā’ir) i Marakeša (francuski Marrakech, arapski Murrākuš) te ime otoka Džerbe (francuski Djerba, arapski Ǧirba).

Ruski jezik govori se u najvećoj zemlji na svijetu, pa nije neobično da mnogobrojni objekti koji se nalaze u Rusiji, a pritom su najčešće i prostrani, imaju hrvatske prilagođenice. Osim toga, iz ruskoga kao posredničkoga i bliskoga nam, slavenskoga jezika doslovno smo preuzimali ili prilagođavali imena iz bližih, ali i nekih dalekih zemalja i jezika s prostora nekadašnjeg SSSR-a, najviše u Ukrajini, Uzbekistanu, Turkmenistanu i kavkaskim državama (npr. ukrajinski Čornobyl’ prilagođen je kao Černobil preko ruskog Černobyl' i pod kasnijim utjecajem engleskoga Chernobyl /prema Gluhak 2003-04/; uzbečki Buxoro preuzet je iz ruskoga kao Buhara; azerbajdžanska Culfa prilagođena je kao Džulfa prema ruskom Džul'fa; turkmenski Garagum prilagođen je kao Karakum preko ruskoga Karakumy). Neke egzonime nastale iz ruskoga i danas rabimo jer su se ustalili u hrvatskom jeziku (npr. Harkov, Kijev, Lavov), ali smo većinu zamijenili endonimima ili prilagođenicama nastalim iz neruskih jezika (npr. uz Černobil pojavljuje se ime Čornobilj prema ukrajinskom Čornobyl'). Mnogi su egzonimi nastali i zbog nedosljedne transliteracije s ruske ćirilice (npr. Anadir / Anadir', Irtiš / Irtyš, Jenisej / Enisej, Kazanj / Kazan'), ali i zbog katkad višekratnih preimenovanja imena naselja u bivšem SSSR-u i nakon njegova raspada i s tim povezanoga nastanka novih prilagođenica (npr. ukrajinski grad Dnipro, prilagođen kao Dnjepar preko ruskog Dnepr ili Dnjipro prema ukrajinskom Dnipro, više je puta mijenjao ime. U nas se prema ruskim inačicama zapisivao kao Dnjepropetrovsk, /J/Ekaterinoslav i Novorosijsk).

Budući da je »arapski jezik službeni ili jedan od službenih jezika u dvadeset zemalja« (Kovačić 2019: 149) te je njegov utjecaj zbog arapskih i turskih osvajanja daleko širi jer zahvaća golema prostranstva - do Španjolske i Portugala u Europi, a 
njihovim osvajanjima i drugdje po svijetu - razumljivo je da je arapski jezik jedan od najzastupljenijih jezika izvornih imena hrvatskih egzonima. Osim toga, za arapski je jezik, prema Kovačiću karakteristično da nema standardizirani latinični oblik pa se prilikom prenošenja znakova u latinicu često slijedi francuska i engleska transliteracija. U hrvatskom se, međutim, pri pisanju izvornih arapskih imena na latinici služi i sustavom transliteracije arapskoga pisma koji je razvilo Njemačko orijentalističko društvo (Deutsche Morgenländische Gesellschaft - DMG). Prema hrvatskim pravopisima imena iz arapskoga jezika pišu se prema uobičajenom izgovoru u hrvatskom jeziku (npr. Abu Dabi, Alep, Bejrut, Damask, Džerba). Upravo ta različitost u prenošenju znakova arapskoga pisma u hrvatski jezik jedan je od razloga postojanja hrvatskih egzonima nastalih iz arapskoga jezika, ali i pojave višeimenosti, tj. velike neujednačenosti u pisanju toponima za isti objekt (npr. za Ar-Riyāḍ pojavljuju se inačice Rijad, Riad, Riyad, Riyadh, Riat; za Al-Ḩarțūm zabilježena su inačice Kartum, Khartoum, Hartum).

Brojnost hrvatskih prilagođenica nastalih iz ostalih jezika (njemački do hebrejski na dijagramu) uvelike se podudara s brojnošću egzonima prema državama, što se objašnjava djelomičnim podudaranjem jezičnih i državnih granica. Zbog dugotrajnih ekonomskih, kulturnih i jezičnih dodira sa zajednicama koje ih govore iz njih smo stvorili prilagođenice. Slično kao i kod raspodjele prema državama, najviše egzonima nastaje iz jezika koji su: a) nam geografski bliže pa su i jezični utjecaji dugotrajniji i jači (npr. njemački, talijanski, mađarski, rumunjski, turski), unatoč tomu što neke lako pišemo i izgovaramo; b) rašireni i utjecajni svjetski jezici u povijesti ili danas, često u prostorno velikim zemljama s mnogo velikih i važnih objekata. Ovdje se ubrajaju kineski, španjolski, hindski, portugalski te latinski, grčki, farski (perzijski) i turski; c) bliski nam slavenski jezici. Uz ruski, to su ukrajinski i poljski.

Mnogi su hrvatski egzonimi nastali zbog različitih sustava prenošenja pisama u hrvatski jezik, odnosno zbog razlika u grafičkoj i fonetskoj prilagodbi, što znači da su promjene vrlo male (npr. turski Çeşme nekada smo pisali Češme, rumunjski Bucureşti nama je Bukurešt, mađarski Erdély pišemo Erdelj, a Mohács Mohač, talijanski Appennini prilagodili smo kao Apenini, a toponim Campania pišemo kao Kampanija). Premda izvorna imena iz latiničnih jezika lako čitamo i pišemo pa bi bilo logično da nemamo mnogo egzonima (prema Jordan 2011), zbog utjecaja posredničkoga jezika ili zbog prilagođavanja našoj abecedi (npr. zamjene slova $\mathrm{w}, \mathrm{x}$, y sa slovima v, ks, i/j; poljski Kraków u hrvatskom je Krakov, a Beskidy su Beskidi) i lakšega izgovora, nastali su brojni egzonimi. Kad popis/baza koji je poslužio za istraživanje ne bi bio opsežan, takvi se egzonimi ne bi uzimali u obzir. Osim toga, mnogi su egzonimi nastali i zbog razumljive, lako prevodive opće imenice (generičkoga dijela imena) (npr. njemački Achensee preveli smo kao Achensko jezero, Bayerische Alpen kao Bavarske Alpe, Schwarze Elster kao Crni Elster, talijanski Lago di Garda kao Gardsko jezero). Nadalje, povijesna imena iz latinskoga i grčkoga jezika, kao i u osta- 
lim jezicima, uglavnom imaju svoje prilagođenice, a najčešće je riječ o imenima povijesnih pokrajina, država, važnijih gradova (npr. Abesinija, Akvileja, Antiohija, Biblos, Efez, Galicija, Mizija), što podupire tvrdnju o važnosti objekta te bliskosti i dugotrajnosti veza s njime kao preduvjetima za stvaranje egzonima.

\section{Zaključak}

Kvantitativnom analizom brojnosti i zastupljenosti hrvatskih egzonima u nekoliko kategorija (tip i lokacija geografskoga objekta te jezik izvornoga imena) potkrijepljenom brojnim primjerima potvrđeno je da se hrvatski egzonimi uporabljuju sukladno globalnim kriterijima uporabe egzonima koji se odnose na geografski objekt. To znači da se rabe:

a. kad geografski objekt ima bliske i tradicionalne veze s hrvatskom jezičnom zajednicom (npr. Bavarska, Beč, Budimpešta, Rim, Trst, Venecija). Uporaba hrvatskih egzonima tada upućuje na dugotrajne društveno-političke, ekonomske, kulturne i jezične dodire hrvatske jezične zajednice s drugim zajednicama, odnosno na utjecaje koju su druge kulture izravno ili posredno imale na razvoj naše kulture i jezika. Upućuje i na obrnuto proporcionalni odnos između udaljenosti objekata od hrvatskih govornika i broja egzonima. Potvrđeno je da se više objekata s hrvatskim egzonimima nalazi u državama (najviše u susjednim zemljama) i jezičnim zajednicama koje su nam geografski bliže.

b. kad je geografski objekt povijesno ili danas važan, globalno i/ili za hrvatske govornike (npr. Alep, Bejrut, Franačka, Fukušima, Himalaja, Kalifornija). Uporaba hrvatskih egzonima tada upućuje na općeprihvaćenu važnost objekata, kako u svjetskim razmjerima, tako i za hrvatske govornike (koja se može i ne mora podudarati s njegovom važnosti na svjetskoj razini). Osim prostranih objekata, važnost kojih se očituje u njihovoj veličini, poput mora, planinskih sustava, golemih nizina i visoravni, podmorskih hrptova i sl., to mogu biti i manji povijesno, ekonomski (osobito u prometu i pomorstvu) i kulturno važni objekti, poput morskih prolaza i kanala, svjetskih luka, planinskih prijevoja, poprišta bitki, povijesnih regija i naselja. Egzonimi važnih objekata postoje i u drugim jezicima. Hrvatskim su govornicima važni i strani objekti vezani uz događaje iz hrvatske političke, ekonomske i kulturne povijesti (npr. Mohač, Pečuh, Solun).

c. kad se geografski objekt prostire na više govornih područja (npr. Alpe, Drava, Dunav, Karpati, Rajna). Uporaba hrvatskih egzonima tada može upućivati na prostranost tih objekata, što je najčešće povezano s njihovom važnosti u svjetskim razmjerima, na možebitno prekogranično pružanje tih objekata is tim povezan zajednički suverenitet nad njima te na postojanje egzonima u drugim jezicima. 


\section{LITERATURA}

Beránek, Tomáš i dr. (2006). Index českých exonym: Standardizované podoby, varianty. Prag: Český úřad zeměměřický a katastrální.

Borčić, Branko (1975). Toponimika i kartografija. Geodetski list, 29/52, str. 15-25.

Breu, Josef (1987). Exonyms - categories and degree of use of exonyms: Exonyms in cartography. Fifth United Nations Conference on the Standardization of Geographical Names, E/CONF.79/L.6, https://unstats.un.org/unsd/geoinfo/UNGEGN/docs/5th-uncsgn-doc/e_conf79_L6.pdf (pristupljeno 26. VI. 2017).

Brozović Rončević, Dunja (2011). Exonyms as a reflection of cultural heritage. Twentieth Session of the East Central and South-East Europe Division of the UNGEGN, ECSEED/Session.20/2011/27, http://ungegn.dgu.hr/ungegn20/27_CRO_ECSEED_Documets_Brozovic_Exonyms.pdf (pristupljeno 13. I. 2019).

Crljenko, Ivana, Klemenčić, Mladen (2011). Geografska imena u leksikografskim izdanjima. U: Zbornik radova Prvog nacionalnog znanstvenog savjetovanja o geografskim imenima. Zadar: Sveučilište u Zadru, str. 105-110.

Crljenko, Ivana (2017). Metoda klasifikacije u istraživanjima egzonima / Classification Method in Exonym Studies. Hrvatski geografski glasnik, 79/1, str. 81-106.

Crljenko, Ivana (ur.) (2018). Hrvatski egzonimi II - popis suvremenih i povijesnih egzonima. Zagreb: Leksikografski zavod Miroslav Krleža.

Crljenko, Ivana (2019). Otvorena pitanja o pisanju i uporabi hrvatskih egzonima na kartama / Open Questions on Writing and the Use of Croatian Exonyms on Maps. Kartografija i geoinformacije, 18/31, str. 26-59.

Cvitanović, Alfonso (1974). Pisanje i čitanje geografskih naziva. U: Veliki atlas svijeta. Beograd i Ljubljana: Prosveta i Mladinska knjiga, str. 393-399.

Dollimore, Allison, Watanabe, Kohei (ur.) (2019). The Classification of Exonyms. Hamburg: Verlag Dr. Kovač.

Gluhak, Alemko (2003-04). Ruska i neka druga imena u hrvatskom jeziku danas. Folia onomastica Croatica, 12-13, str. 163-181.

Gostl, Igor (1985). Egzonimi: prilog teoretskom pristupu. fezik, 32/3, str. 78-88.

Hajčiková, Marta, Kováčóva, Mária (1999). Slovenské vžité názvy geografických objektov ležiacich mimo územia Slovenskej republiky. Bratislava: Úrad geodézie, kartografie a katastra Slovenskej republiky.

Hakulinen, Kerkko, Paikkala, Sirkka (2013). Pariisista Papukaijannokkaan. Suomenkieliset ulkomaiden paikannimet ja niiden vieraskieliset vastineet. Helsinki: Kotimaisten kielten keskus.

Harvalík, Milan (2016). The Types of Czech Exonyms and Incorporating Foreign Geographical Names into Czech. U: Proceedings of the 25th International Congress of Onomastic Sciences (Toponomastics I). Glasgow: University of Glasgow, str. 180-186.

Jordan, Peter (2009). Place names as ingredients of space-related identity. U: Geographical Names as a Part of the Cultural Heritage. Vienna: Institut für Geographie und Regionalforschung der Universität Wien, str. 33-39.

Jordan, Peter (2011). Trends of Exonym Use in European School Atlases. U: Proceedings of the 25th International Cartographic Conference, CO-376, https://icaci.org/files/documents/ICC_proceedings/ ICC2011/Oral\%20Presentations\%20PDF/D4-Toponyms\%20on\%20maps\%20and\%20on $\% 20$ GeoDB/CO-376.pdf (pristupljeno 28. IV. 2020).

Jordan, Peter (2017a). Report of the Working Group on Exonyms. Eleventh United Nations Conference on the Standardization of Geographical Names, E/CONF.105/23/CRP.23, https://unstats.un.org/ unsd/geoinfo/UNGEGN/docs/11th-uncsgn-docs/E_Conf.105_23_CRP.23_6_Report\%20of\%20 the\%20Working\%20Group\%20on\%20Exonyms\%20Conference.pdf (pristuplieno 4. IV. 2020). 
Jordan, Peter (2017b). »Exonym use: Globally common characteristics and criteria«. Eleventh United Nations Conference on the Standardization of Geographical Names, E/CONF.105/16/CRP.16, https://unstats.un.org/unsd/geoinfo/UNGEGN/docs/11th-uncsgn-docs/E_Conf.105_16_ CRP.16_11_Exonym\%20use.pdf (pristupljeno 4. IV. 2020).

Kladnik, Drago (2001). Seznam tujih zemljepisnih imen v slovenskem jeziku. Ljubljana: Geodetska uprava Republike Slovenije.

Kladnik, Drago (2007). Types of exonyms in the Slovene language. U: Exonyms and the International Standardisation of Geographical Names. Wien i Berlin: LIT VERLAG GmbH \& Co. KG i LIT VERLAG Dr. W. Hopf, str. 119-131.

Kladnik, Drago i dr. (2013). Slovenski eksonimi. Ljubljana: Založba ZRC.

Kovačić, Marko (2019). Prilagodba stranih toponima u hrvatskom jeziku. Zagreb: Matica hrvatska.

Ormeling, Ferjan (2012). Exonyms in cartography. UNGEGN-ICA webcourse on Toponymy, https://unstats.un.org/unsd/geoinfo/UNGEGN/docs/_data_ICAcourses/_HtmlModules/_Documents/ D13/Documents/D13-01_Ormeling.pdf (pristupljeno 2. IV. 2020).

Woodman, Paul (2007a). Exonyms and UNGEGN: An unhappy history. U: Exonyms and the International Standardisation of Geographical Names. Wien i Berlin: LIT VERLAG GmbH \& Co. KG i LIT VERLAG Dr. W. Hopf, str. 7-10.

Woodman, Paul (2007b). Exonyms: A structural classification and a fresh approach. U: Exonyms and the International Standardisation of Geographical Names. Wien i Berlin: LIT VERLAG GmbH \& Co. KG i LIT VERLAG Dr. W. Hopf, str. 11-17.

Zych, Maciej (prir.) (2013). Urzędowy wykaz polskich nazw geograficznych świata. Warszawa: Głowny Urząd Geodezji i Kartografii.

URL 1: United Nations Group of Experts on Geographical Names (UNGEGN), https://unstats.un.org/ unsd/ungegn/ (pristupljeno 3. IV. 2020).

URL 2: UNGEGN Working Group on Exonyms (WGE), http://ungegn.zrc-sazu.si/Home.aspx (pristupljeno 3. IV. 2020).

URL 3: Resolutions Adopted at the Eleven United Nations Conferences of the Standardization of Geographical Names. 2017. Natural Resources Canada, https://unstats.un.org/unsd/ungegn/documents/RES_UN_E_updated_1-11_CONF.pdf (pristupljeno 4. IV. 2020).

URL 4: Texts of Resolutions on the Subject of Exonyms, http:/ungegn.zrcsazu.si/Portals/7/WGE\%20 Activities/Resolutions_on_exonyms.pdf (pristupljeno 4. IV. 2020).

URL 5: Rječnik stranih geografskih imena, https://www.lzmk.hr/projekti/154-rjecnik-stranih-geografskih-imena (pristupljeno 2. V. 2020).

URL 6: Guidelines for the Preparation of Lists of Exonyms, Fifteenth Session of the United Nations Group of Experts on Geographical Names, W.P. 76, https://unstats.un.org/unsd/geoinfo/UNGEGN/docs/15th-gegn-docs/15th_gegn_WP76.pdf (pristupljeno 12. IV. 2020).

URL 7: Zapisnici i zaključci sjednica Vijeća za normu hrvatskoga standardnog jezika (2005.-2012.), http://pravopis.hr/uploads/vijece-za-normu.pdf (pristupljeno 9. IV. 2020).

URL 8: Second United Nations Conference on the Standardization of Geographical Names, Vol. II. Tehnical papers, E/CONF.61/4/Add.1, https://unstats.un.org/unsd/geoinfo/UNGEGN/ docs/2nd-uncsgn docs/E_Conf61_4_Add1_e.pdf (pristupljeno 14. IV. 2020).

URL 9: Glossary of Terms for the Standardization of Geographical Names. 2002. New York: United Nations Publications, https://unstats.un.org/unsd/geoinfo/UNGEGN/docs/pubs/Glossary_of_ terms_rev.pdf (pristupljeno 10. IV. 2020).

URL 10: Názvy geografických objektov z územia mimo SR http:/www.skgeodesy.sk/sk/ugkk/geodeziakartografia/standardizacia-geografickeho-nazvoslovia/nazvy-geografickych-objektov-z-uzemia-mimo-sr/ (pristupljeno 15. IV. 2020). 
URL 11: Eksonyymit, http://kaino.kotus.fi/eksonyymit/?a=oikeinkirjoitus\&s=eksonyymien_kaytto (pristupljeno 15. IV. 2020).

URL 12: The Gazetteer of Slovenian Exonyms, http:/ungegn.zrc-sazu.si/Documents/THEGAZETTEEROFSLOVENIANEXONYMS.aspx (pristupljeno 9. IV. 2020).

URL 13: Slovar slovenskih eksonimov, https:/www.termania.net/slovarji/129/slovar-slovenskih-eksonimov (pristupljeno 15. IV. 2020).

\title{
AN ANALYSIS OF THE USE OF CROATIAN EXONYMS IN REGARD TO THE CHARACTERISTICS OF A GEOGRAPHICAL FEATURE
}

\author{
Ivana Crljenko \\ The Miroslav Krleža Institute of Lexicography, Zagreb \\ ivana.crljenko@1zmk.hr
}

\begin{abstract}
The use of exonyms is one of the earliest challenges faced by experts who deal with geographical names on an international level. The prevalent view is that exonyms hinder international communication and their use should therefore be reduced. Another opinion is that exonyms are a constituent part of the vocabulary of the linguistic community that creates and uses them, an important part of cultural heritage and identity, and should therefore not be overlooked. Recently, the idea that a middle ground should be found is gaining traction; according to it, exonyms should be used differently depending on the users' age groups, the purpose of the publication they appear in, and the type of communication (international or national). Following this view, members of the UNGEGN Working Group on Exonyms have reached conclusions regarding the globally shared characteristics of exonyms and the criteria of their use. Three criteria are related to the characteristics of the geographical features for which the exonym is used (type, size, importance, familiarity, and location). Qualitative analysis of the number and distribution of Croatian exonyms in several categories shows that the use of Croatian exonyms is in accordance with these criteria. This means that exonyms are used: a) when a geographical feature has close and traditional ties with the Croatian linguistic community - most commonly features that are geographically nearby; b) when the feature is historically or currently important, globally and/or for Croatian language speakers; c) when the feature covers more than one speaking area.
\end{abstract}

Keywords: Croatian exonyms; loanwords; use of exonyms; UNGEGN 